\title{
Determinants of the Disclosure Level of the Pillar 3 Recommendations of the Basel II Accord in the Financial Statements of Brazilian Financial Institutions
}

\author{
Lidiano de Jesus Santos ${ }^{\dagger}$ \\ Rio de Janeiro Federal University - UFRJ \\ Marcelo Alvaro da Silva Macedo ${ }^{\Omega}$ \\ Rio de Janeiro Federal University - UFRJ \\ Adriano Rodrigues ${ }^{\sharp}$ \\ Rio de Janeiro Federal University - UFRJ
}

\begin{abstract}
The objective of this article is to identify the determinants of the disclosure level of the information recommended by Pillar 3 of the Basel II Accord for the 100 largest banking institutions active in Brazil. For this purpose, we first analyze the disclosure level of each institution and then seek the determinants of this disclosure level. We start from five hypotheses, based on the following variables: size, nationality, voting concentration, type of capital and Basel index. To test these hypotheses we use difference of means tests and multiple regression analysis, at a $10 \%$ level of significance. We find that size, Basel index and type of capital are significant, meaning they are able to explain the disclosure level of the information analyzed. On the other hand, voting concentration and nationality are not significant.
\end{abstract}

Keywords: Disclosure. Basel 2. Financial institutions.

* Author for correspondence:

${ }^{\dagger}$.Master's in Accounting from Rio de Janeiro Federal University Address: Av. Pasteur, 250 - (sala 250) - FACC/UFRJ - Urca, Rio de Janeiro - RJ - Brazil

E-mail: lidianojesus@ bol.com.br Telephone: (21) 8426-1287
${ }^{\Omega}$ Habilitation in Control and Accounting from the University of São Paulo

Institution: Professor in the Graduate Program of UFRJ.

Address: Av. Pasteur, 250 - (sala 250)

- FACC/UFRJ - Urca, Rio de

Janeiro - RJ - Brazil

E-mail: malvaro.facc.ufrj@gmail.com

Telephone: (21) 3873-5262

\footnotetext{
${ }^{¥} \mathrm{Ph} . \mathrm{D}$ in Control and Accounting from the University of São Paulo. Institution: Professor in the Graduate Program of UFRJ

Address: Av. Pasteur, 250 - (sala 250) -

FACC/UFRJ - Urca, Rio de Janeiro -

$\mathrm{RJ}$ - Brazil

E-mail: adriano@facc.ufrj.br

Telephone: (21) 3873-5262
}

Note from the Editor: This article was accepted by Bruno Funchal. (cc) $\mathrm{BY}$

This article has a Creative Commons License - Attribution 3.0 Not Adapted. 


\section{INTRODUCTION}

isclosure is the act of revealing, divulging or disseminating information. In

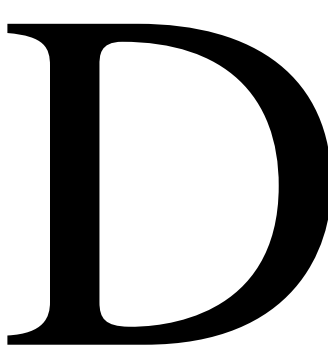
the corporate setting, the purpose of disclosure is to reduce the information asymmetry between managers and other stakeholders/market participants. Some firms disclose more information than is legally required, a practice known as voluntary or discretionary disclosure. According to Múrcia \& Santos (2010), this occurs because the controllers of the company have additional information whose disclosure is not obligatory, so they have the option to reveal it in certain cases.

Whether mandatory of voluntary, the disclosure of financial information is important to evaluate investment opportunities, both by managers to make decisions on investment projects and investors in deciding on how to allocate assets in their portfolios most efficiently among the various options in the market (BUSHMAN; SMITH, 2003).

The disclosure of financial institutions is of particular importance, not only to allow investors to evaluate investment opportunities, but also to allow the market and regulators to assess their risk exposure, which is crucial due to the possible impacts on the global economy of a banking crisis.

In 1974, the Basel Committee on Banking Supervision was created with the aim of increasing collaboration among bank supervisors. Among its activities, the committee recommends accords to reduce the impacts of systemic risk and increase the financial stability of banks, and consequently of the global economy. The accord currently in effect is the Basel II Accord, which is composed of three pillars: Pillar 1 - Capital Requirement, Pillar 2 Banking Supervision, and Pillar 3 - Transparency and Market Discipline.

Our focus here is on the third Pillar (transparency), involving disclosure of information structured according to the Basel II Accord, to allow the market to have a clear and concise understanding of the risks to which each financial institution is exposed.

In this sense, our objective is to identify the determinants of the level of disclosure of the information recommended by Pillar 3 for the 100 largest financial institutions in Brazil in 2010. For this purpose, we address the following questions:

- What is the level of disclosure of the information recommended by Pillar 3 of the Basel II Accord by the banks under analysis?

- What are the determinants of this disclosure level? 
Our main motivations are the fact there are few studies aimed at identifying the determinants of disclosure focused on banking institutions and the importance of transparency of these institutions, in view of the risks to which they are exposed and the possible economic impacts of a banking crisis.

The article is divided into five sections including this introduction. In the second section we review the main points of disclosure of accounting information, while in the third we explain the methodology, before analyzing the results in the fourth section. The fifth section concludes.

\section{DISCLOSURE OF ACCOUNTING INFORMATION}

Disclosure should not be confused with the revelation of information in general, since information may or may not be relevant to understanding the true situation of a firm. According to Gibbins, Richardson \& Waterhouse (1990), disclosure is the revelation of quantitative or qualitative information through formal and informal channels that is useful to users.

According to Lima (2007), disclosure can be either mandatory or discretionary. The first case covers, for example, disclosure requirements for listing on stock exchanges and to meet periodic requirements of securities commissions or trade associations in countries. In turn, the second category covers the announcement of information meant to provide greater transparency, such as social or environmental responsibility reports.

In this respect, Pillar 2 of Basel II, which covers transparency and market discipline, was received by the Brazilian Central Bank and is applicable to the institutions belonging to the National Financial System, according to Communication 12,746/2004:

The Board of Governors of the Central Bank of Brazil, in a session held on
December 8, 2004, in light of the recommendations of the Basel Committee on
Banking Supervision (Committee) contained in the document "International
Convergence of Capital Measurement and Capital Standards: A Revised Structure"
(Basel 2), which involves the establishment of criteria that are most suitable to the
risk levels of the transactions carried out by financial institutions for the purpose of
regulatory capital requirements, has established the observance of those guidelines,
adapted to the conditions, peculiarities and stage of development of the Brazilian
market, by adopting the following procedures to implement Basel 2, stressing that
the recommendations contained in Pillar 2 (Supervision Process) and in Pillar 3
(Transparency and Market Discipline) shall be applied to all institutions of the
National Financial System - emphasis added (FERREIRA; ARAÚJO, 2004).

With the objective of explaining the reasons firms voluntarily disclose information, various researchers have sought to develop analytical models based on economic premises to provide a theoretical framework for research on the matter. Among these, we can mention 
Singhvi \& Desai (1971), Ahmed \& Courtis (1999), Verrecchia (2001), Dye (2001), Goulart (2003), Salloti (2005), Lima (2007) and Murcia (2009). All of these studies have examined, to a greater or lesser degree, the relations between some economic parameters and the disclosure level in a specific market.

In this context, Ahmed \& Courtis (1999) carried out a study to verify and indicate the difference factors in the results of empirical studies aimed at identifying the association between corporate characteristics and disclosure level. The authors confirmed, for a determined group of companies, the hypothesis of an association between the level of disclosure and the size of the firm.

Another study that deserves mention is that of Salotti (2005). Based on disclosure theory, he assessed the reasons for publishing a cash flow statement (not mandatory for listed Brazilian firms before 2008), considering five hypotheses relating voluntary publication of this statement to other variables. The evidence suggested correlations with some of the variables studied: positive - with the importance given by the company to the perceptions of outsiders and with performance of the company; or negative - with disclosure costs and information asymmetry.

Also in this sense, Murcia (2009) tried to identify the factors that explain the level of voluntary disclosure of publicly traded companies in Brazil. Based on the theory of discretionary disclosure, he found an association between the disclosure level and the economic sector, and found some variables to be significant for the disclosure models tested, namely: sector, origin of control, profitability, size, issuance of shares, growth and concentration of control.

A final work that warrants mention on the importance of disclosure is Lima (2007). The aim was to evaluate the relationship between the disclosure level and the cost of debt capital. The author expected that increased disclosure would result in reduced information asymmetry, lowering the risk to lenders and the cost of capital. The results bore out this expectation, indicating an inverse relationship between the level of voluntary disclosure and the cost of debt capital. In other words, the greater the level of voluntary disclosure, the lower the cost of financing was of the firms studied.

More specifically, some important studies have been published based on the theory of disclosure applied to financial institutions. For example, Xavier (2003) concluded that the disclosure by banks in Brazil was at an incipient stage, since they disclosed only $26 \%$ of the 
items examined, in comparison to a rate of $63 \%$ in a similar study conducted by the Basel Committee.

A more recent study of this matter, corroborating the earlier opinion, is Britto et al. (2011), who sought to verify the level of disclosure of government-controlled banks in Brazil in relation to the recommendations of Pillar 3 of the Basel II Accord. The evidence suggested that the transparency of public-sector banks in the period studied was incipient, with the information disclosed mainly being that which banks must reveal according to law or regulations. In numbers, the disclosure level was $25 \%$ for the fourth quarter of 2008 and $29 \%$ for 2009 as a whole.

In turn, Goulart (2003) focused on a specific aspect of disclosure by Brazilian financial institutions: market risk. The findings indicated that while advances had occurred in the disclosure level of market risk information, the transparency was still low in comparison with international practices.

Also in this line, Torres (2011) studied the disclosure level in the banking sector in light of Brazilian regulatory rules, specifically Circular 3,477/2009 from the Central Bank. The aim was to verify the level of disclosure of information regarding risk management in light of the Circular and the characteristics of the institutions with higher disclosure levels. The findings indicated that only $50(49.5 \%)$ of the banks analyzed disclosed the information required by Circular 3,477 in a single place, with easy public access, at the institution's website, as the Circular's Art. 15 requires. The results also indicated that government-controlled banks disclosed more of the required information $(65.22 \%)$ than did privately owned banks (59\%), and that for both types, information of a quantitative character was more prevalent. Among the determining variables of the disclosure level, size, derivatives and leverage had a statistically significant relationship with the disclosure level variable.

\section{METHODOLOGY}

\subsection{GENERAL ASPECTS}

To identify the determinants of the disclosure level of the information recommended by Pillar 3 of the Basel II Accord for the 100 larges Brazilian banking institutions in 2010, we conducted the study in two phases:

- Analysis of the disclosure level of each institution studied; and

- Identification of the determinants of this disclosure level. 
Therefore, the first part of this article, according to the classification of Vergara (2009), is exploratory and descriptive in nature, since it reports the level of disclosure of each institution with respect to Pillar 3 by analyzing the information disclosed in the financial statements of these banks. The second part is descriptive and explanatory in nature, with an empirical-positivist approach, which according to Martins \& Theóphilo (2009), involves techniques for collection, treatment and analysis of data, mainly quantitative, where the validation of scientific evidence is achieved by tests of instruments, degrees of significance and systematization of operational definitions.

\subsection{RESEARCH HYPOTHESES}

Considering our purpose of identifying the determinants of the disclosure level of banks in relation to the requirements of Pillar 3 of the Basel II Accord, we formulated some hypotheses for empirical testing, based on previous studies of the determinants of the disclosure level of voluntary information.

According to Verrecchia (2001), in theory the absence of disclosure costs presupposes complete disclosure. The assumption in this case is that the disclosure costs are relatively lower for larger companies since they are better able to bear the expenses of the disclosure process. From this supposition, the disclosure level is expected to be directly related to the size of the company. Other studies, such as those of Ahmed \& Courtis (1999), Murcia (2009) and Braga, Oliveira \& Salotti (2009), have confirmed this reasoning. Therefore, we formulated the following hypothesis, adapted to your research problem.

- H1: The size of a bank positively influences the disclosure of the information recommended by Pillar 3 of the Basel II Accord.

According to Murcia (2009), by agency theory the managers of companies with higher indebtedness tend to voluntarily disclose more information, basically for the purpose of reducing the risk perception of providers of debt capital (JENSEN; MECKLING, 1976).

In this study, since our focus is on banks, we sought to associate the Basil indicator to the debt level measure applied to nonfinancial companies. The reason is that the Basel indicator proposes that financial institutions should have a minimum capital level (required reference equity or bank net equity) to support possible losses resulting from the risks to which they are exposed. The main preoccupation is that banks be solid enough so that a systemic crisis will not compromise the financial stability of banks in general and thus of the global economy. 
As can be seen, the Basel indicator also to a certain extent represents, like the indebtedness of nonfinancial firms, a proxy for capital risk. In other words, it is related to banks' capital structure.

In this context, we start from the idea that banks with a low Basel index are viewed as riskier by investors, causing them to demand a greater return on the capital invested, increasing the cost of capital. In this situation, a higher disclosure level should work to allay the risk perception of investors by lowering the information asymmetry (Braga; Oliveira \& Salotti, 2009). The following hypothesis reflects this expectation.

-H2: A bank's Basel index negatively influences the disclosure level of the information recommended by Pillar 3 of the Basel II Accord.

Among the supposed factors related to firms' disclosure level is the influence of the accounting practices of the home country (SILVA et al., 2007). According to Hackston \& Milne (1996), the nationality of the shareholding control can be a determining variable of the level of environmental disclosure.

Therefore, we assume that companies in a more internationalized environment should be more willing to disclose information, due to questions of a cultural order, level of exposure and the need to comply with requirements of other countries, among other factors. In this context, the next hypothesis relates this variable considering the research problem.

- H3: Financial institutions with foreign shareholding control have a higher disclosure level than those having Brazilian shareholding control with respect to the information recommended by Pillar 3 of the Basel II Accord.

Dantas et al. (2010), in discussing the possible forms of disclosure, emphasized that self-induced disclosure mechanisms are typically present when the dynamics between firms and investors force the former to disclose more information.

Therefore, we believe that listed companies, because they must have higher governance standards, will be more informative than unlisted companies, leading to the following hypothesis concerning banks.

- H4: Financial institutions listed on the BM\&FBovespa have a higher disclosure level than do unlisted banks regarding the information recommended by Pillar 3 of the Basel II Accord. 
Finally, we pay heed to the idea that the demand for information is lower from firms with more concentrated shareholding, since the controlling shareholders already have privileged access to information (ALENCAR, 2007). This hypothesis was confirmed by Murcia \& Santos (2010).

This pattern is also found by Murcia (2009), because investors with larger percentage holdings can more easily obtain information, such as through their representatives on the board of directors.

Therefore, banks with more dispersed shareholding should have a higher level of disclosure than those with more concentrated ownership structures, leading to the following hypothesis regarding Brazilian banks.

- H5: Financial institutions with more dispersed shareholding structure have a greater disclosure level than banks with more concentrated ownership structure with respect to the information recommended by Pillar 3 of the Basel II Accord.

\subsection{UNIVERSE, SAMPLE AND INFORMATION ANALYZED}

At first we analyzed the 100 largest Brazilian banks (classified by total assets), in December 2010, according to the list published by the Brazilian Central Bank (www.bcb.gov.br).

We dropped some of these banks from the sample. We eliminated government development banks because they have different objectives than other banks. The banks excluded for this reason were BNDES, BRDE, BDMG and BANDES. We also dropped banks that did not present a Risk Management Report, because this prevented analysis of the disclosure of these banks. Finally, we were unable to find the percentages of voting concentration regarding the capital structure of three financial institutions. After applying these filters, the final sample consisted of 47 institutions in the first part (analysis of the disclosure level) and 46 in the second part (identification of the determinants of the disclosure level).

The data for the first part of the analysis were obtained from the Risk Management Report, found at each institution's website, referring to the 2010 fiscal (calendar) year.

To operationalize the five hypotheses and carry out the examinations of the second part of the analysis, we selected variables (proxies) based on data from various sources. Chart 1 identifies the variables used and the respective data sources. 


\begin{tabular}{|l|c|c|c|}
\hline Hypotheses & Variables & Expected Sign & Data Source \\
\hline I. Size (SIZE) & Ln of Total Assets & + & Brazilian Central Bank \\
\hline II. Basel Index (BAS) & Basel Index & - & Brazilian Central Bank \\
\hline $\begin{array}{l}\text { III. Nationality of Control } \\
\text { (NATC) }\end{array}$ & $\begin{array}{c}\text { 1 for National Control } \\
\text { 0 for Foreign Control }\end{array}$ & DNA & Brazilian Central Bank \\
\hline IV. Type of Capital (CAP) & $\begin{array}{c}\text { 1 for Publicly Traded } \\
\text { 0 for Closely Held }\end{array}$ & DNA & $\begin{array}{c}\text { Brazilian Securities } \\
\text { Commission (CVM) }\end{array}$ \\
\hline $\begin{array}{l}\text { V. Concentration of Votes } \\
\text { (CONC) }\end{array}$ & $\begin{array}{c}\text { of Common Shares of } \\
\text { Main Shareholder }\end{array}$ & $\begin{array}{c}\text { Reference Form (CVM) for } \\
\text { listed banks and banks' websites }\end{array}$ \\
\hline
\end{tabular}

Chart 1 - Summary of Hypotheses and Explanatory Variables

DNA: Does not apply

Source: Prepared by the authors.

By analyzing these independent variables, we sought to explain the dependent variable, called the disclosure index (DI). We formulated a proxy for this variable as follows: (i) for each bank, we analyzed the disclosure or not of information in each category recommended; (ii) if present, the item received the value of 1 , and 0 otherwise; (iii) then we added the values of all the items analyzed and divided the sum by the number of items, to obtain the disclosure index (DI) for the information recommended by Pillar 3 of the Basel II Accord.

We should mention here an important limitation of this study, namely the incomplete separation between voluntary and mandatory information. We believe that the disclosure requirements of the Central Bank (according to National Monetary Council Resolution 3,477/2009) are within the scope of the Pillar 3 recommendations. However, we did not undertake any empirical verification of the size of the intersection between these two regulatory frameworks. In other words, of the information categories recommended by Pillar 3 of the Basel II Accord, we did not separate or identify those that are not required by the Brazilian Central Bank based on CMN Resolution 3,477/2009. This can mean that some of the information disclosed was not voluntary.

\subsection{INSTRUMENTS FOR ANALYSIS OF THE DATA}

For the first part of the study, we used content analysis of the financial information evaluated. Martins \& Theóphilo (2009, p. 98) define content analysis as "a technique to study and analyze communication objectively and systematically." The aim of this technique is to draw reliable inferences from data and information regarding a determined context, based on discourse analysis. One of the main objectives of this technique is to audit the content of communications and then compare the findings with determined patterns and/or objectives, justifying the use of content analysis here.

The list of elements to be analyzed referring to the recommendations of Pillar 3 of the Basel II Accord was based on the article of Britto et al. (2011). Besides that study, a similar 
analysis was conducted by Ferreira \& Araújo (2004). In this respect, we examined the presence or absence of disclosure of the following groups of information recommended by Pillar 3, as shown in Table 1 (appendix): (i) Capital Structure; (ii) Capital Adequacy; (iii) Credit Risk; (iv) Securitization; (v) Market Risk; (vi) Equity Investments; and (vii) Interest Rate Risk.

For each bank we analyzed the disclosure of each item composing the groups listed above, so that a value of 1 was attributed when the recommended information was present and 0 when absent. The disclosure index (DI) was computed by dividing the total number of points assigned by the number of recommended items.

In the second part of the study, we used two analytic instruments: difference of means testing and regression analysis.

To test the hypotheses $\boldsymbol{H 1}, \boldsymbol{H 2}, \boldsymbol{H 3}, \boldsymbol{H 4}$ and $\boldsymbol{H 5}$, we applied multiple regression analysis, with DI as the dependent variable and size (SIZE), Basel index (BAS), nationality of control (NATC), type of capital (CAP) and concentration of shares (CONC) as the independent variables. Therefore, we applied the following regression model:

$$
\mathrm{ID}_{\mathrm{i}}=\alpha_{0}+\alpha_{1} \operatorname{SIZE}_{i}+\alpha_{2} B A S_{i}+\alpha_{3} N A T C_{i}+\alpha_{4} C A P_{i}+\alpha_{5} C O N C_{i}+\varepsilon_{i}
$$

Following the orientations of Gujarati (2006), Corrar, Paulo \& Dias Filho (2007) and Fávero et al. (2009), to estimate the regression we used the ordinary least squares (OLS) method. Besides this, to test the model as a whole, we applied the F-test, whose null hypothesis $\left(\mathrm{H}_{0}\right)$ is that $\mathrm{R}^{2}$ is equal to zero. Additionally, to test the coefficients of the variables, we ran a t-test, in which the null hypothesis is that the coefficients are equal to zero.

With respect to the assumptions of the regression, to test the normality of the residuals, we used the Jarque-Bera (JB) test, while for homoscedasticity of the residuals we applied the Breusch-Pagan-Godfrey (BPG) test and for multicollinearity of the variables, we used the variance inflation factor (VIF) statistic, according to which the regression is considered accepted when VIF is less than 5.00. Finally, regarding autocorrelation, according to Fávero et al. (2009) there is no need to test for this when working with cross-sectional data, as in the present study.

The data set used presented the problem of selection bias, defined by Lennox, Francis \& Wang (2012) as a problem related to the lack of observations for the dependent variable. In our case, not all the banks (the largest 100) disclosed a Risk Management Report, so those 
that did not had to be dropped from the sample. To correct for that bias, we used the two-stage procedure proposed by Heckman (1979), in which the first stage involved using a probit regression with all the banks, in which disclosure or not of that report was a dependent dummy variable. That procedure aimed to obtain the inverse Mills ratio for incorporation in the regression presented above. This made the estimated coefficients robust to the problem of selection bias. The significance of this new variable (inverse Mills ratio) indicates the existence or not of the selection bias problem.

Since the number of banks analyzed was small (only 46 institutions), we decided to use a difference of means test as complementary analysis for the nominal dichotomic variables of the regression model. This decision was based on the possible impairment of the results of the regression analysis by degree of freedom problems caused by the excess number of variables in comparison with the number of observations. This is another limitation of the results found.

With this, to test hypotheses $\boldsymbol{H 3}$ and $\boldsymbol{H 4}$ we applied, besides regression, a difference of means test. However, before this we verified the normality of the disclosure index (dependent variable), because only when this variable is normally distributed can the t-test (parametric test) for difference of means be applied. If the dependent variable is not normally distributed, one must opt for a nonparametric test, such as the Mann-Whitney test.

The idea of applying the difference of means test to the disclosure index (DI) was to verify if average indexes were the same or different between the national and foreign-owned banks and between the listed and unlisted ones, considering a certain level of significance $(10 \%)$. A statistically significant variable between the groups means the variable is a determinant of the disclosure level.

All the difference of means tests were carried out with the SPSS 17.0 program. In the case of the regressions, the analysis, except for the VIF calculation (also done using SPSS 17.0), was performed with Eviews 6.0. In all cases, we considered a 10\% significance level.

\section{ANALYSIS OF THE RESULTS}

In the evaluation of the disclosure index (DI) of all the banks analyzed, considering all the elements listed in Table 1 (in the appendix), we obtained the results reported in Chart 2. It can be seen that the dependent variable DI presents values between $20 \%$ and $54 \%$, showing a certain heterogeneity of the institutions with respect to disclosure of the information recommended by Pillar 3 of the Basel II Accord. It can also be seen that the average DI was 
$37 \%$, with half of the banks presenting a figure below $38 \%$, according to the descriptive statistics shown in Chart 3.

\begin{tabular}{|l|c|l|c|}
\hline \multicolumn{1}{|c|}{ Institutions } & DI (\%) & \multicolumn{1}{c|}{ Institutions } & DI (\%) \\
\hline BB & $49 \%$ & BRB & $35 \%$ \\
\hline ITAU & $51 \%$ & PINE & $31 \%$ \\
\hline BRADESCO & $52 \%$ & FIDIS & $22 \%$ \\
\hline CEF & $38 \%$ & MORGANSTANLEY & $28 \%$ \\
\hline SANTANDER & $46 \%$ & CNHCAPITAL & $20 \%$ \\
\hline HSBC & $46 \%$ & INDUSVAL & $35 \%$ \\
\hline VOTORANTIM & $49 \%$ & MERRILLLYNCH & $52 \%$ \\
\hline SAFRA & $45 \%$ & BANIF & $31 \%$ \\
\hline CITIBANK & $34 \%$ & CSF & $42 \%$ \\
\hline BTGPACTUAL & $23 \%$ & BANESE & $38 \%$ \\
\hline BANRISUL & $35 \%$ & INDUSTRIALDOBRASIL & $35 \%$ \\
\hline DEUTSCHE & $23 \%$ & HONDA & $33 \%$ \\
\hline CREDITSUISSE & $31 \%$ & BANPARA & $42 \%$ \\
\hline BNB & $54 \%$ & STANDARDBI & $50 \%$ \\
\hline BNPPARIBAS & $35 \%$ & GOLDMANSACHS & $46 \%$ \\
\hline VOLKSWAGEN & $29 \%$ & SMBC & $40 \%$ \\
\hline BIC & $49 \%$ & ING & $20 \%$ \\
\hline JPMORGANCHASE & $26 \%$ & MODAL & $38 \%$ \\
\hline BMG & $38 \%$ & GUANABARA & $38 \%$ \\
\hline FIBRA & $32 \%$ & MORADA & $28 \%$ \\
\hline BANESTES & $42 \%$ & INTERMEDIUM & $31 \%$ \\
\hline MERCANTILDOBRASIL & $46 \%$ & RIBEIRAOPRETO & $29 \%$ \\
\hline CRUZEIRODOSUL & $35 \%$ & STANDARDCHARTEREDBIS.A. & $42 \%$ \\
\hline RABOBANK & $38 \%$ & & \\
\cline { 1 - 3 } Ch & &
\end{tabular}

Chart 2 - Disclosure Indexes (DI) of the Financial Institutions Analyzed

Source: Prepared by the authors.

\begin{tabular}{|l|r|}
\hline Minimum & $20 \%$ \\
\hline Maximum & $54 \%$ \\
\hline Mean & $37 \%$ \\
\hline Lower Quartile & $31 \%$ \\
\hline Median & $38 \%$ \\
\hline Upper Quartile & $45 \%$ \\
\hline
\end{tabular}

Chart 3 - Descriptive Statistics - Disclosure Indexes (DI)

Source: Prepared by the authors.

In the following subitems, based on the information shown in Table 1 (appendix), which show the percentage of disclosure of each information item recommended by Pillar 3 , we evaluate all the elements that support these percentages reported in Chart 2.

\subsection{CAPITAL STRUCTURE}

The capital structure was evaluated based on the information obtained in the Risk Management Report presented by the financial institutions for 2010. 
Item 1.1 (Summary of the terms and conditions of capital instruments), which is the only qualitative information category of the capital structure chart, was only disclosed by $26 \%$ of the banks analyzed (BB, Santander, CEF, Banco Bic, Banco BMG, Mercantil do Brasil, Banco Pine, BTG Pactual, MerrillLynch, GoldmanSachs, SMBC and Banco Guanabara).

The items "amount of tier 1 capital" and "amount of tier 2 capital" were the most often disclosed, by $98 \%$ of the banks. This is explained by the fact that these two tiers compose the reference equity, a parameter of overarching importance for the sector and that is basically extracted from the accounts, making it easier to disclose. In turn, information on "minority interests in the equity of subsidiaries" was the least disclosed item (11\% of the institutions).

BB was the most informative institution regarding structure items, disclosing information on $100 \%$ of the items.

\subsection{CAPITAL ADEQUACY}

Considering that the Brazilian Central Bank opted for progressive implementation of the Basel II Accord, starting with application of the standardized approaches, we only verified the recommendations related to these approaches. This type of analysis was previously conducted for Brazil by Britto et al. (2011) and Ferreira \& Araújo (2004).

The information on credit, market and operational risk had the highest disclosure levels in the "capital requirement" group, disclosed by $100 \%, 94 \%$ and $98 \%$, respectively, of the banks analyzed. This can be explained by the fact that those three requirements are part of the "required reference equity" category, which is necessary for calculating the reference index of the banking sector, the Basel index.

In turn, information on "total and tier 1 capital index" was only disclosed by $2 \%$ of the banks. This is due to the fact this index was not incorporated into the Brazilian regulatory framework by the Central Bank.

Bradesco and Citibank were the banks with the best disclosure of the capital adequacy items, both with $86 \%$ disclosure rates.

\subsection{CREDIT RISK}

The disclosure of credit risk according to Pillar 3 is divided into three groups: (i) general disclosure; (ii) standardized portfolio; and (iii) mitigation.

Regarding general disclosure for all banks, presented in Table 1 (appendix), information on the definition of past due or impaired loans appeared in the reports of nearly all the banks 
analyzed. This can be explained by the fact this information is required by Central Bank Circular 3,477/2009. Indeed, the two most disclosed requirements were "definition of past due/impaired loans" and "discussion of the bank's credit policy", with $87 \%$ and $79 \%$, respectively.

In contrast, some information was not disclosed by any of the banks, such as residual maturity of the entire loan book segmented by the main types of exposure, specific provisions (and the respective charges) and general provisions, segmented by type of sector or counterparty, and impaired loans. Reflection is thus warranted regarding the information recommended by Basel II on this requirement and the business model of Brazilian financial institutions.

With respect to the portfolios subject to the standardized approach, only $17 \%$ of the banks disclosed some information. Just as for general disclosure, this warrants reflection on the adequacy of the information to the business model of Brazilian banks or the reasons they practically do not disclose the approach to which the portfolio is subject.

Regarding credit risk mitigation, the most frequently disclosed items were: (i) policies and processes for on and off balance sheet netting (72\% of the banks); (ii) policies and processes for evaluation and management of guarantees (53\% of the banks); and (iii) information on the credit or market risk concentration within the mitigation adopted (64\% of the banks), as shown in Table 1 in the appendix. The only banks that disclosed information in $100 \%$ of the recommended categories were Banco Safra and Bradesco.

\subsection{SECURITIZATION}

Table 1 also shows that the disclosure level regarding securitization was very low. The items most disclosed by the banks in their Risk Management Reports involved the most basic information on the subject, such as: (a) objectives in relation to securitization; and (b) total amount securitized by the bank and subject to the securitization structure. Both these items were disclosed by $24 \%$ of the institutions analyzed.

This unfavorable result agrees with the finding of Britto et al. (2011), based on banks' Quarterly Financial Information reports.

\subsection{MARKET RISK}

With respect to market risk, all the banks disclosed information in more than $80 \%$ of the categories. This can be explained by the fact that the components of the "market risk" disclosure category are for the most part represented by risk-weighted equity items $\left(\mathrm{P}_{\mathrm{ACS}}\right.$, 
$\mathrm{P}_{\mathrm{JUR}}, \mathrm{P}_{\mathrm{OPR}}$ and $\mathrm{P}_{\mathrm{CAM}}{ }^{1}$ ), all of which are necessary to calculate the Basel index. The average disclosure index for this category was $85 \%$.

\subsection{EQUITY INVESTMENTS}

On the matter of equity investments, the disclosure level was incipient, since information regarding only two items was disclosed by more than $15 \%$ of the banks, namely: (i) the types and nature of investments, including the amounts that can be classified as exchange traded and private equity investments (disclosed by $23 \%$ of the banks) and (ii) capital requirements segmented by appropriate grouping of stocks - which is included in the required reference equity (disclosed by $64 \%$ of the banks).

In summary, the disclosure by Brazilian banks on the risk from equity holdings is very poor. The cumulatively realized gains (or losses) from sale and liquidation of equity investments and the total unrealized gains (or losses) are among the categories in which information was not disclosed by any banking institution. Since these data have an accounting nature, according to Table 1 (appendix), we believe they are found more often in strictly accounting reports (which is not the case of the Risk Management Report).

\subsection{INTEREST RATE RISK}

Regarding the interest rate risk, Cruzeiro do Sul, Santander, Banpara, SMBC and Standard Chartered BI S.A. disclosed information regarding $100 \%$ of the required items. However, the overall disclosure level of this group of items for all the banks was relatively low, as shown in Table 3. The item with the highest DI was disclosed by only $13 \%$ of the banks analyzed.

As stated before, some of the information recommended by Pillar 3 of the Basel II Accord is required by the Brazilian Central Bank, according to CMN Resolution 3,477/2009. However, based on the supposition that banks comply with the mandatory reporting requirements, the demands of the Central Bank only cover about $20 \%$ of the recommended information items. With this, despite the concerns expressed at the end of the methodology section as possible limitations of the results, the DI values for the sample can be taken as revealing that nearly $80 \%$ of the information items recommended by Pillar 3 of the Basel II Accord are voluntary in Brazil, an aspect that did not bring any major problems to the analyses conducted.

\footnotetext{
${ }^{1} \mathrm{P}_{\mathrm{ACS}}=$ portion of risk subject to variations in stock prices; $\mathrm{P}_{\mathrm{JUR}}=$ portion of risk subject to variations in interest rates; $\mathrm{P}_{\mathrm{OPR}}=$ portion of risk subject to variations in operational risk; $\mathrm{P}_{\mathrm{CAM}}=$ portion of risk subject to variations in exchange rates, as defined by the Central Bank.
} 


\subsection{ANALYSIS OF THE DETERMINANTS OF THE DISCLOSURE LEVEL}

The results of the regression are shown in Table 1.

Table 1 - Results of the Regression Analysis

\begin{tabular}{|c|c|c|c|c|}
\hline $\begin{array}{c}\text { Explanatory or } \\
\text { Independent Variable }\end{array}$ & Coefficient & Standard Error & $t$ & p-value \\
\hline SIZE & 0,0232 & 0,0034 & 6,8293 & $<0,0000$ \\
\hline BAS & 0,0010 & 0,0005 & 1,9948 & 0,0531 \\
\hline NATC & 0,0353 & 0,0240 & 1,4741 & 0,1485 \\
\hline CAP & 0,0272 & 0,0246 & 1,1094 & 0,2740 \\
\hline $\mathrm{CONC}$ & $-0,0040$ & 0,0531 & $-0,0757$ & 0,9401 \\
\hline Mills & 0,0193 & 0,0749 & 0,2575 & 0,7982 \\
\hline $\mathrm{C}$ & $-0,0411$ & 0,0758 & $-0,5423$ & 0,5907 \\
\hline Additional Information & Values & \multicolumn{2}{|c|}{ Additional Information } & Values \\
\hline $\mathrm{R}^{2}$ & 0,3592 & \multicolumn{2}{|l|}{ F (estat.) } & 3,6436 \\
\hline Adjusted $\mathrm{R}^{2}$ & 0,2606 & \multicolumn{2}{|l|}{ F (p-value) } & 0,0058 \\
\hline Jarque-Bera (stat.) & 0,0761 & \multicolumn{2}{|c|}{ Breusch-Pagan-Godfrey (F stat.) } & 2,5065 \\
\hline Jarque-Bera (p-value) & 0,9626 & \multicolumn{2}{|c|}{ Breusch-Pagan-Godfrey (p-value) } & 0,0379 \\
\hline
\end{tabular}

It can be observed that the $\mathrm{R}^{2}$ of $26.06 \%$ is significant at $10 \%$, since the $\mathrm{p}$-value of the F-test is lower than this level. This shows that the variation of the independent variables analyzed is able to explain $26.06 \%$ of the variation of the disclosure index.

This is confirmed, as expected, by the t-test of the variables SIZE and BAS, which shows their coefficients are significantly different from zero, given that the p-value in both cases is lower than $10 \%$. However, the same does not apply to CONC, NATC and CAP, for which the p-value is higher than the significance threshold established.

There were no problems of normality of the residuals or multicollinearity, since the Jarque-Bera test's p-value is greater than 0.10 and the VIF values are all below 1.70 . However, there were problems of heteroscedasticity of the residuals, based on the p-value of the Breusch-Pagan-Godfrey test lower than $10 \%$. Because of this, we estimated the coefficients with White correction to make them robust to heteroscedasticity.

Finally, the Mills variable was not significant in the model. As said in the methodology section, this shows there is no problem of selection bias. Nevertheless, the inclusion of the variable makes the coefficients of the other variables robust to selection bias.

From this analysis of the regression it can be concluded that only the variables size and Basel index had a determining influence on the disclosure level of the information recommended by Pillar 3 of the Basel II Accord in the period studied. Therefore, the results confirm hypotheses $\boldsymbol{H} \mathbf{1}$ and $\boldsymbol{H} \mathbf{2}$ and do not confirm $\boldsymbol{H 3}, \boldsymbol{H 4}$ and $\boldsymbol{H 5}$. 
What called our particular attention in the results was the sign of the coefficient of BAS, because we expected a negative sign, but it turned out to be positive and significant. This result can indicate that to mitigate the problem of adverse selection, the managers of banks with better performance - in this case better Basel index (lower risk) - tend to disclose more information. This incentive to engage in actions that better and more extensively demonstrate the institution's situation finds support in signaling theory (Beaver, 1998). In other words, the objective of managers is to transmit a "signal" to the market of the bank's better situation in comparison to rivals, to "induce" favorable decisions.

In turn, the failure to confirm the influence of ownership concentration can be associated with the fact this measure presented small dispersion. In other words, because of the small sample size, the variable was relatively homogeneous, with many banks (more than half) having a percentage of $100 \%$ and some others with percentages near $100 \%$. This caused a problem of almost zero and non-significant correlation, generating a lack of significance of this variable in the regression.

As mentioned in the methodology section, to analyze the explanatory potential of the variables nationality of control (NATC) and type of capital (CAP), which were not significant in the regression analysis, we performed a complementary difference of means tests.

First we checked whether the dependent variable disclosure index (DI) was normally distributed. The p-value of the Shapiro-Wilk test was 0.145 , showing that the $\mathrm{H}_{0}$ that the variable has distribution tending to normal could not be rejected. With this we could apply the t-test for difference of means for independent samples. However, we opted to present the results of the Mann-Whitney test, since our sample is small (46 observations). The results for each independent variable are reported in Table 2.

Table 2 - Results of the Difference of Means Tests

\begin{tabular}{lccccc}
\hline $\begin{array}{c}\text { Independent } \\
\text { Variable }\end{array}$ & $\begin{array}{c}\text { P-value of the } \\
\text { Levene test }\end{array}$ & Value of $\mathrm{t}$ & $\begin{array}{c}\text { P-value of } \\
\text { the t-test }\end{array}$ & $\begin{array}{c}\text { P-value of } \\
\text { the MW } \\
\text { test }\end{array}$ & Conclusion \\
\hline NATC & 0,403 & $-1,446$ & 0,155 & 0,149 & Accept $\mathrm{H}_{0}$ \\
\hline CAP & 0,841 & $-2,677$ & 0,010 & 0,009 & Reject $\mathrm{H}_{0}$ \\
\hline
\end{tabular}

From Table 3, it can be seen that in all cases, according to the p-value of the Levene test, the variances assume equal values for the t-test. The results of the p-values of the difference of means tests indicate that only for the groups of the CAP variable are the means of the disclosure index different at $10 \%$ significance. This means that this variable is capable 
of explaining the disclosure level of the information recommended by Pillar 3. In other words, the nationality of control is not statistically significant as a determinant of the disclosure level in the difference of means test as well, confirming hypothesis $\boldsymbol{H 4}$, but the same does not hold for $\boldsymbol{H 3}$.

Finally, the sign of the t-statistic shows that in the case of type of capital, the banks listed on the BM\&FBovespa $(\mathrm{CAP}=1)$ tend to disclose more information than their unlisted counterparts $(\mathrm{CAP}=0)$, exactly as predicted.

\section{FINAL CONSIDERATIONS}

Our main focus was to investigate empirically the disclosure level of the information recommended by Pillar 3 of the Basel II Accord for the 100 largest Brazilian banks in 2010 and to identify the determinants of this disclosure. For this purpose, we analyzed the Risk Management Reports of the banks, obtained from their websites, referring to 2010. Only $47 \%$ (47/100) of the institutions published this report, reducing the sample size. We also investigated in this context the relationship between economic variables and the disclosure level of the banks analyzed.

The dependent variable disclosure index (DI) presented values ranging from $20 \%$ to $54 \%$, showing a certain heterogeneity of the institutions in relation to disclosure of the information recommended by Pillar 3. The values found here exceed those reported by Britto et al. (2011) for an earlier period (fourth quarter of 2008 and all of 2009).

According to the multiple regression analysis, the $\mathrm{R}^{2}$ value showed that the variation of the independent variables examined explained $26.06 \%$ of the variation of the disclosure index, at $10 \%$ significance. Besides this, the coefficients of the variables SIZE and BAS were significantly different from zero, since the p-value for both was lower than $10 \%$. However, the same cannot be said for NATC, CAP and CONC, for which the p-values were higher than that significance level.

This shows that for the regression analysis, only banks' size and Basel index are determinants of the disclosure level of the information recommended by Pillar 3 of the Basel II Accord, confirming hypotheses $\boldsymbol{H} \mathbf{1}$ and $\boldsymbol{H} \mathbf{2}$ and not confirming $\mathrm{H3}, \boldsymbol{H} \mathbf{4}$ and $\boldsymbol{H 5}$. The failure to confirm the hypothesis for shareholding concentration can be associated with the fact that this index had very little dispersion in the sample. 
Although there are limitations for comparison, the results of this study run counter to those reported by Torres (2011), who found evidence that the variables representing size, derivatives and leverage were statistically significant to explain the level of disclosure.

An important question in the results of this study is the sign of the Basel index variable (BAS). It was positive and significant, indicating that banks with better Basel indexes (lower risk) tend to disclose more information for the purpose of mitigating the adverse selection bias and to signal to the market a more advantageous position versus competitors.

Besides this, in the difference of means tests for the variables nationality of control (NATC) and type of capital (CAP), only for CAP did the two groups (publicly traded and unlisted banks) present different disclosure indexes, at $10 \%$ significance. This means that although not significant in the regression, this variable is able to explain the disclosure level of the information recommended by Pillar 3, confirming only hypothesis $\boldsymbol{H 4}$, since for $\boldsymbol{H 3}$ the results sustained those found in the regression analysis.

In summary, among the variables studied, only nationality of control and concentration of votes were not significant as determinants of the disclosure level of Pillar 3 information. Therefore, size, Basel index and type of capital appear to be factors that explain the disclosure level of this type of information by Brazilian banks.

For future research, we suggest qualitative distinction and comparison of the information recommended by Pillar 3 of the Basel II Accord (used in this study) and the disclosure requirements of the Brazilian Central Bank (CMN Circular 3,477/2009). We believe this will more clearly identify, within the Pillar 3 recommendations, what types of information disclosure are really voluntary in Brazil. Besides this, we also suggest new studies based only on Brazilian regulatory rules.

\section{REFERENCES}

AHMED, K.; COURTIS, J. Associations between corporate characteristics and disclosure levels in annual reports: a meta-analysis. The British Accounting Review, v. 31, n. 1, p. 35$61,1999$.

ALENCAR, R. Nível de disclosure e custo de capital próprio no mercado brasileiro. 2007. 104 f. Tese (Doutorado em Controladoria e Contabilidade) - Faculdade de Economia, Administração e Contabilidade, Universidade de São Paulo, 2007.

BEAVER, W. Financial reporting: an accounting revolution. New Jersey: Prentice Hall, 1998. 
BLUM, D.; NAKANE, M. I. O impacto de requerimentos de capital na oferta de crédito bancário no Brasil. In: ENCONTRO NACIONAL DOS CENTROS DE PÓS-GRADUAÇÃO EM ECONOMIA, 33., 2005, Natal. Anais... Natal-RN: ANPEC, 2005. CD-ROM.

BM\&FBOVESPA. Nível de governança corporativa. Disponível em: <www.bmfbovespa.com.br>. Acesso em: 06 fev. 2012.

BRAGA, J. P.; OLIVEIRA, J. R. S.; SALLOTI, B. M. Determinantes do nível de divulgação ambiental nas demonstrações contábeis de empresas brasileiras. Revista de Contabilidade da UFBA, v. 3, n. 3, p. 81-95, 2009.

BRITTO, A. S.; RODRIGUES, A.; MARQUES, J. A. V. C. Divulgação nos relatórios dos bancos públicos brasileiros: análise das recomendações do Pilar 3 do Acordo de Basiléia 2. In: CONGRESSO DA ASSOCIAÇÃO NACIONAL DE PROGRAMAS DE PÓSGRADUAÇÃO EM CIÊNCIAS CONTÁBEIS, 5., 2011, Vitória-ES. Anais... Vitória-ES: AnpCONT, 2011. CD-ROM.

BUSHMAN, R.; SMITH, A. Transparency, financial accounting information and corporate governance. FRBNY Economic Policy Review, v. 9, n. 1, p. 65-87, 2003.

CORRAR, L. J.; PAULO, E.; DIAS FILHO, J. M. (Coord.). Análise multivariada para cursos de administração, ciências contábeis e economia. São Paulo: Atlas, 2007.

DANTAS, J. A. et al. Determinantes do grau de evidenciação de risco de crédito pelos bancos brasileiros. Revista Contabilidade \& Finanças, v. 21, n. 52, art. 1, 2010.

DYE, R. An evaluation of "essays on disclosure" and the disclosure literature in accounting. Journal of Accounting and Economics, v. 32, n. 1-3, p. 181-135, 2001.

FÁVERO, L. P. et al. Análise de dados: modelagem multivariada para tomada de decisões. Rio de Janeiro: Campus Elsevier, 2009.

FERREIRA, C.; ARAÚJO, E. Disclosure em instituições financeiras: uma análise comparativa entre Basiléia II e a prática brasileira. In: SEMANA DE CONTABILIDADE DO BANCO CENTRAL, 10., 2004, Brasília. Anais... Brasília: BCB, 2004. p. 73-92. Disponível em: <http://www.bcb.gov.br>. Acesso em: 12 ago. 2011.

GIBBINS, M.; RICHARDSON, A.; WATERHOUSE, J. The management of corporate financial disclosure: opportunism, ritualism, policies, and process. Journal of Accounting Research, v. 28, n. 1, p. 121-143, 1990.

GOMES, P. H. V. et al. Análise do nível de adesão ao disclosure do risco operacional pelos bancos com ações negociadas na BM\&FBovespa. In: CONGRESSO USP DE CONTROLADORIA E CONTABILIDADE, 11., 2011, São Paulo. Anais... São Paulo: EAC-FEA-USP, 2011. CD-ROM.

GOULART, A. M. C. Evidenciação contábil do risco de mercado por instituições financeiras no Brasil. 2003. 201 f. Dissertação (Mestrado em Controladoria e Contabilidade) - Faculdade de Economia, Administração e Contabilidade, Universidade de São Paulo, 2003.

GUJARATI, D. Econometria básica. Rio de Janeiro: Campus Elsevier, 2006. 
HACKSTON. D.; MILNE, M. J. Some determinants of social and environmental disclosures in New Zealand companies. Accounting, Auditing and Accountability Journal, v. 9, n. 1, p. 77-108, 1996.

HECKMAN, J. J. Sample selection bias as a specification error. Econometrica, v. 47, n. 1, p. 153-161, 1979.

JENSEN, M.; MECKLING, W. Theory of the firm: managerial behavior, agency costs and ownership structure. Journal of Financial Economics, v. 3, n. 4, p. 305-360, 1976.

LENNOX, C. S.; FRANCIS, J. R.; WANG, Z. Selection models in accounting research. The Accounting Review, v. 87, n. 2, p. 589-616, 2012.

LIMA, G. A. Utilização da teoria da divulgação para avaliação da relação do nível de disclosure com o custo da dívida das empresas brasileiras. 2007. 108 f. Tese (Doutorado em Controladoria e Contabilidade) - Faculdade de Economia, Administração e Contabilidade, Universidade de São Paulo, 2007.

MARTINS, G. A.; THEÓPHILO, C. R. Metodologia da investigação científica para ciências sociais aplicadas. 2. ed. São Paulo: Atlas, 2009.

MURCIA, F. D. Fatores determinantes do nível de disclosure voluntário de companhias abertas no Brasil. 2009. 181 f. Tese (Doutorado em Controladoria e Contabilidade) Faculdade de Economia, Administração e Contabilidade, Universidade de São Paulo, 2009.

MURCIA, F. D.; SANTOS, A. Teoria do disclosure discricionário: evidências do mercado brasileiro no período de 2006-2008. In: CONGRESSO DA ASSOCIAÇÃO NACIONAL DE PROGRAMAS DE PÓS-GRADUAÇÃO EM CIÊNCIAS CONTÁBEIS, 4., 2010, Natal-RN. Anais... Natal-RN: AnpCONT, 2010. CD-ROM.

SALOTTI, B. M. Divulgação voluntária da demonstração dos fluxos de caixa no mercado de capitais brasileiro. 2005. 178 f. Tese (Doutorado em Controladoria e Contabilidade) Faculdade de Economia, Administração e Contabilidade, Universidade de São Paulo, 2005.

SINGHVI, S. S.; DESAI, H. B. An empirical analysis of the quality of corporate financial disclosure. The Accounting Review, v. 46, n. 1, p. 129-138, 1971.

TORRES, Mônica Campos. Analise da aderência do disclosure da gestão de riscos pelas instituições financeiras à circular 3.477 do Bacen. 2011. 72 f. Dissertação (Mestrado em Administração de Empresas) - Fundação Instituto Capixaba de Pesquisas em Contabilidade, Economia e Finanças (FUCAPE), Vitória-ES, 2011.

VERGARA, S. C. Projetos e relatórios de pesquisa em administração. 10. ed. São Paulo: Atlas, 2009.

VERRECCHIA, R. E. Essays on disclosure. Journal of Accounting and Economics, v. 32, n. 1-3, p. 97-180, 2001.

XAVIER, P. H. M. Transparência das demonstrações contábeis dos bancos no Brasil: estudo de caso sob a perspectiva do acordo "Basiléia 2". 2003. 100 f. Dissertação (Mestrado em Controladoria e Contabilidade) - Faculdade de Economia, Administração e Contabilidade, Universidade de São Paulo, 2003. 
YANAKA, G. M.; HOLLAND, M. Basiléia II e exigência de capital para risco de crédito dos bancos no Brasil. Texto para Discussão da FGV-EESP, n. 188, 2009. 
Determinants of the Disclosure Level of the Pillar 3 Recommendations of the Basel II

\section{APPENDIX}

Table 3 - Profile of the Disclosure of Information According to Pillar 3 of the Basel II Accord

\begin{tabular}{|c|c|}
\hline Itens de Divulgação & $\begin{array}{c}\text { Percentual de Bancos } \\
\text { que divulgou }\end{array}$ \\
\hline \multicolumn{2}{|l|}{ 1. Estrutura de capital } \\
\hline (1.1) Resumo sobre os termos e condições dos instrumentos de capital & \\
\hline (1.2) Montante de capital Nível 1 & $98 \%$ \\
\hline (1.3) Participação de capital integralizado & $91 \%$ \\
\hline (1.4) Quantidade de reservas & $55 \%$ \\
\hline (1.5) Participaç̃ão de minoritários no capital de subsidiárias & $11 \%$ \\
\hline (1.6) Quantidade de instrumentos inovadores, complexos ou híbridos & $62 \%$ \\
\hline (1.7) Montante de capital Nível 2 & $98 \%$ \\
\hline (1.9) Capital elegivel total & $94 \%$ \\
\hline \multicolumn{2}{|l|}{ 2. Adequacão de capital } \\
\hline $\begin{array}{l}\text { (2.1) Discussão simplificada da metodologia adotada pela instituição para } \\
\text { avaliar a adequação de seu capital próprio para suportar suas atividades atuais } \\
\text { e futuras. }\end{array}$ & $77 \%$ \\
\hline (2.2) Requerimentos de capital para risco de crédito: & $100 \%$ \\
\hline $\begin{array}{l}\text { (2.3) As carteiras sujeitas à metodologia padronizada ou padronizada } \\
\text { simplificada devem ser evidenciadas individualmente. }\end{array}$ & $17 \%$ \\
\hline (2.4) Exposiçōes securitizadas. & 3 \\
\hline (2.5) Requerimentos de capital para suportar risco de mercado. & $94 \%$ \\
\hline (2.6) Requerimentos de capital para suportar risco operacional. & \\
\hline (2.7) Índice de Capital total e nível 1. & $98 \%$ \\
\hline
\end{tabular}

3. Risco de crédito: divulgaçẽes gerais para todos os bancos

Divulgações Qualitativas

\begin{tabular}{|c|c|}
\hline de risco de crédito & \\
\hline (3.1) definiçã̃o de créditos em atraso e problemáticos; & $87 \%$ \\
\hline $\begin{array}{l}\text { (3.2) descrição dos métodos seguidos para provisionamentos específicos e } \\
\text { gerais e métodos estatísticos; }\end{array}$ & $49 \%$ \\
\hline (3.3) discussão da política de crédito do banco. & $79 \%$ \\
\hline Divulgações Quantitativas & \\
\hline $\begin{array}{l}\text { (3.4) Exposição total a risco de crédito e exposição total média no período, } \\
\text { segmentadas por tipo de operação de crédito. }\end{array}$ & $77 \%$ \\
\hline $\begin{array}{l}\text { (3.5) Distribuição geográfica dos créditos, segmentada em áreas significativas } \\
\text { por tipos de exposiçăo. }\end{array}$ & $60 \%$ \\
\hline $\begin{array}{l}\text { (3.6) Distribuição das exposições por setor ou tipo de contraparte, segmentada } \\
\text { por tipo de operação. }\end{array}$ & $77 \%$ \\
\hline $\begin{array}{l}\text { (3.7) Maturidade residual dos contratos de toda a carteira, segmentada pelos } \\
\text { principais tipos de exposição. }\end{array}$ & $0 \%$ \\
\hline (3.8) Segmentados pelo tipo de setor ou de contraparte: & \\
\hline $\begin{array}{l}\text { (3.9) montante de créditos problemáticos e, se disponível, empréstimos em } \\
\text { atraso, fornecidos separadamente; }\end{array}$ & $6 \%$ \\
\hline (3.10) provisões específicas e gerais;e & $0 \%$ \\
\hline (3.11) encargos das provisões específicas. & $0 \%$ \\
\hline $\begin{array}{l}\text { (3.12) Montante de empréstimos problemáticos, se disponível, empréstimos en } \\
\text { atraso providos separadamente segmentados por áreas geográfica } \\
\text { significativas, incluindo, se possível, os montantes de provisōes específicas } \\
\text { gerais relativas a cada área geográfica }\end{array}$ & $0 \%$ \\
\hline $\begin{array}{l}\text { (3.13) Reconciliação de mudanças nas provisões para empréstimos } \\
\text { problemáticos. }\end{array}$ & $0 \%$ \\
\hline
\end{tabular}
problemáticos.

4. Risco de crédito: disclosures para carteiras sujeitas a metodologia padronizada

Divulgações Qualitativas

Para carteiras sob o modelo padronizado:

(4.1) Nomes das instituições externas de avaliação de crédito e agências de avaliação de crédito usadas, além das razões para quaisquer mudanças; $\frac{\text { (4.2) Tipos de exposição para os quais cada agência é usada; }}{\text { (4.3) Descriç̃o do processo usado para transferir ratings públicos de ativo }}$ comparáveis aos detidos pelo banco; e

(4.4) O mapeamento entre as escalas de avaliação de cada entidade externa usada com os adotados pela instituição financeira.

$\frac{\text { Divulgaçōes Quantitativas }}{\text { (4.5) Para os montantes expostos após a mitigação de riscos sujeitos ao }}$ (15) saldos da instituição em cada classe de risco bem como aqueles que são deduzidos.

\section{Mitigação de risco de crédito}

Disclosure qualitativo relativo à mitigação de risco de crédito inclui

(5.1) Políticas e processos para compensacão dentro e fora do balanç

(5.2) Políticas e processos para avaliação e gestão de garantia

(5.3) Uma descrição dos principais tipos de garantias recebidas pelo banco.

dentro da mitiocão adota

(5.5) Para cada carteira de risco de crédivulgaçes Quantitativas

exposição total que é coberta por garantias financeiras elegíveis.

(5.6) Para cada carteira de risco de crédito evidenciada separadamente,

exposição total que é coberta por garantias ou derivativos de crédito.

\begin{tabular}{|c|c|}
\hline Itens de Divulgação & $\begin{array}{c}\text { Percentual de Bancos } \\
\text { que divulgou }\end{array}$ \\
\hline \multicolumn{2}{|l|}{ 6. Securitização } \\
\hline \multicolumn{2}{|l|}{ Divulgações Qualitativas } \\
\hline \multicolumn{2}{|l|}{ Disclosure qualitativo relativo à securitização, abrangendo uma discussão de: } \\
\hline \begin{tabular}{|l|} 
(6.1) Objetivos do banco em relação à atividade de securitização, incluindo a \\
extensão a que essas atividades transferem risco de crédito das exposiçōes \\
securitizadas pelo banco para outras entidades.
\end{tabular} & $24 \%$ \\
\hline \begin{tabular}{|l|} 
6.2) As funçõ̃es desempenhadas pelo banco no processo de securitização e \\
uma indicação da extensão do envolvimento do banco em cada umaa delas.
\end{tabular} & $6 \%$ \\
\hline $\begin{array}{l}\text { (6.3) As metodologias de determinaç̃ão do capital regulatório que o banco } \\
\text { segue em suas atividades de securitização. }\end{array}$ & $0 \%$ \\
\hline \multicolumn{2}{|l|}{$\begin{array}{l}\text { (6.4) Sumário das políticas contábeis do banco para as atividades de } \\
\text { securitização, incluindo: }\end{array}$} \\
\hline (6.5) Se as transações são tratadas como vendas ou financiamentos. & $6 \%$ \\
\hline $\begin{array}{l}\text { (6.6) Consideraçōos importantes na avaliação de juros retidos, incluindo } \\
\text { quaisquer mudanças importantes desde o último período de publicação e o } \\
\text { impacto de tais mudanças. }\end{array}$ & $0 \%$ \\
\hline $\begin{array}{l}\text { (6.7) Tratamento de securitizaçōes sintéticas, se não cobertas por outras } \\
\text { políticas contábeis. }\end{array}$ & $0 \%$ \\
\hline $\begin{array}{l}\text { (6.8) Nomes das entidades externas de avaliação de risco de crédito usadas } \\
\text { para as securitizaçose en tipos de exposição da securitização para o qual } \\
\text { cada agência é usada. }\end{array}$ & $0 \%$ \\
\hline \multicolumn{2}{|l|}{ Divulgaçōes Quantitativas } \\
\hline \begin{tabular}{|l} 
(6.9) O montante total dos valores securitizados pelo banco e sujeitos à \\
estrutura de securitizacão, por tipo de exposicão.
\end{tabular} & $24 \%$ \\
\hline \multirow{2}{*}{\multicolumn{2}{|c|}{$\begin{array}{l}\text { (6.10) Para as exposições securitizadas pelo banco e sujeitas ao arcabouço da } \\
\text { securitizaçõo: }\end{array}$}} \\
\hline & $3 \%$ \\
\hline $\begin{array}{l}\text { (6.12) Perdas reconhecidas pelo banco durante o período corrente } \\
\text { segmentadas por tipo de exposição. }\end{array}$ & $6 \%$ \\
\hline $\begin{array}{l}\text { 6.13) Montante agregado de exposições de securitização retidas ou compradas } \\
\text { segmentadas por tipo de exposiça. }\end{array}$ & $21 \%$ \\
\hline $\begin{array}{l}\text { 6.14) Para securitizações sujeitas a tratamentos de amortização antecipada, por } \\
\text { tipo de ativo para os arranjos de securitização, as exposiçōes agregadas } \\
\text { sacadas atribuídas aos interesses do vendedor e dos investidores. }\end{array}$ & $0 \%$ \\
\hline $\begin{array}{l}\text { (6.15) Sumário da atividade de securitizacâã do ano atual, incluindo o montante } \\
\text { de exposiços securitizadas (por tipo de exposição), e os ganhos ou perdas } \\
\text { reconhecidas na venda, por tipo de ativo. }\end{array}$ & $3 \%$ \\
\hline \multirow{2}{*}{\multicolumn{2}{|c|}{$\begin{array}{c}\text { 7. Risco de Mercado } \\
\text { Divulgaçōes Qualitativas }\end{array}$}} \\
\hline & \\
\hline $\begin{array}{l}\text { (7.1) Disclosure qualitativo para risco de mercado incluindo as carteiras } \\
\text { cobertas pelo modelo padronizado. }\end{array}$ & $91 \%$ \\
\hline \multirow{2}{*}{\multicolumn{2}{|c|}{ 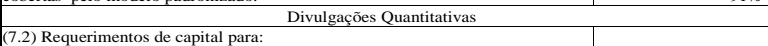 }} \\
\hline & \\
\hline (7.3) Risco de taxa de juros & $91 \%$ \\
\hline (7.4) Risco de ações & $81 \%$ \\
\hline (7.5) Risco cambial & $81 \%$ \\
\hline (7.6) Risco de commodities & $81 \%$ \\
\hline 8. & \\
\hline
\end{tabular}

Divulgações Qualitativas

isclosure qualitativo relativo ao risco das ações, incluindo:

sonhos de capital e

por razões de estratégicas

de relacionamento.
Discussões das políticas importantes com relação à avaliação e

tabilização das posições em ações da instituição. Isto inclui as técnicas

tábeis $\mathrm{e}$ as metodologias de avaliação usadas, incluindo as suposiçõ̃es e icas mais relevantes que afet.

vulgações Quantitativas

3) Valor evidenciado no balanço como investimentos, bem como o valor valores publicamente conhecidos, onde o preço da ac̃o é significativame iferente do valor justo.

8.4) Os tipos e a natureza dos investimentos, incluindo o montante que pode ser classificado como: Negociáveis publicamente e Mantidas privadamente.
8.5) Os ganhos (ou perdas) realizados cumulativamente decorrentes de vendas e liquidaçōes no período evidenciado.

8.6) Total de ganhos (ou perdas) não realizados

7) Total de ganhos (ou perdas) decorrentes de reavaliações latentes

valiaçẽes, inclusos em capital de nível 1 ou de nível 2 .

9) Requerimentos de capital segmentados por agrupamento apropriado de

oes, consistente com a metodologia da instituição, bem como os montantes
regados e o tipo de investimentos em ações sujeitos a quaisquer provisões relação aos requerimentos

9. Risco de taxa de juros em itens patrimoniais

Divulgações Qualitativas

Requisito de evidenciação qualitativa geral, incluindo a natureza do

RBB e as consideraçōes mais importantes, incluindo consideraçôes con que não possuam maturidade específica

$\frac{\text { Divulgações Quantitativas }}{92 \text { ) O acréscimo (ou decréscimo) em lucros ou ma valor econômico (ou }}$

nedida relevante usada pela administração) decorrente de choques nas taxas

Juros de acordo com o método adotado para avaliar o IRRBB, segmentado or moeda (quando relevante). 